\title{
OXYGEN-ISOTOPE AND TOTAL BETA-RADIOACTIVITY MEASUREMENTS ON 10 m ICE CORES FROM THE ANTARCTIC PENINSULA
}

\author{
By D. A. PEeL \\ (British Antarctic Survey, Natural Environment Research Council, High Cross, Madingley \\ Road, Cambridge CB3 0ET, England) \\ and $\mathrm{H}$. B. CLAUSEN \\ (Geophysical Isotope Laboratory, University of Copenhagen, Haraldsgade 6, DK-2200 \\ Copenhagen, Denmark)
}

\begin{abstract}
As part of the Glaciology of the Antarctic Peninsula (GAP) programme, the snow cover at 25 stations was sampled to $10 \mathrm{~m}$ depth for oxygen-isotope and total $\beta$-radioactivity analysis. The mean annual oxygen-isotope ratio correlates satisfactorily with $10 \mathrm{~m}$ temperature despite the complex topography of the area and suggests on average that climatic trends in the region are fairly systematic. The relationship with temperature is similar to that derived from a simple model in which an air mass initially of maritime subtropical characteristics is progressively cooled as it moves towards the region. The detailed isotope profiles show that for future deep drilling the most easily interpretable climatic information will be found in the more continental areas-on the east coast and on the plateau in the south of the region. The degree of continentality of particular sites is reflected in the amplitude of the annual wave in the upper portion of the isotope-ratio profile as well as in the accumulation rate.
\end{abstract}

RÉSUMÉ. Mesures de l'isotope de l'oxygène et de la radio-activité béta totale sur des carottes de glace de $10 \mathrm{~m}$ provenant de l'Antarctic Peninsula. Dans le cadre du programme "Glaciology of the Antarctic Peninsula (GAP)", on a prélevé des échantillons de neige jusqu'à $10 \mathrm{~m}$ de profondeur dans le manteau neigeux de 25 stations pour analyser la teneur en isotope de l'oxygene et la $\beta$-radioactivité totale. La teneur moyenne annuelle en isotope de l'oxygène est lièe de manière satisfaisante avec la température sur $10 \mathrm{~m}$ en dépit de la topographie complexe de la zone et tend à faire penser qu'en moyenne les tendances climatiques dans la région sont bien régulieres. La relation avec la température est semblable à celle déduite d'un modèle simple dans lequel une masse d'air à caractéristiques initiales subtropicales maritimes est progressivement refroidie au cours de son mouvement vers cette région. Le profil detaillé de la teneur en isotope montre que, pour les futurs sondages profonds, les informations climatiques les plus faciles à interpréter se trouveront dans les zones les plus continentales-sur la côte est et sur le plateau au sud de la région. Le degré de continentalité de sites particuliers se reflète dans l'amplitude de la poussée annuelle de la partie supérieure du profil du taux d'isotope, comme dans le niveau de l'accumulation.

ZuSAmmenfassung. Messung der Sauerstoff-Isotope und der Gesamt-Betaradioaktivität in $10 \mathrm{~m}$ langen Eisbohrkernen aus der Antarctic Peninsula. Als Teil des Programmes "Glaciology of the Antarctic Peninsula (GAP)" wurden Proben der Schneedecke bis $10 \mathrm{~m}$ Tiefe zur Analyse der Sauerstoff-Isotope und der Gesamt- $\beta$ Radioaktivität an 25 Stationen gewonnen. Das mittlere jährliche Sauerstoff-Isotopenverhältnis stimmt trotz der komplizierten Topographie des Gebietes befriedigend mit der Temperatur in $10 \mathrm{~m}$ Tiefe überein und lässt vermuten, dass die klimatischen Tendenzen in dieser Region im Mittel weitgehend systematisch verlaufen. Die Abhängigkeit von der Temperatur ist ähnlich der, die sich aus einem einfachen Modell ergibt, bei dem eine Luftmasse von ursprünglich maritim-subtropischem Charakter auf dem Weg in die Region allmählich abgekühlt wird. Die detaillierten Isotopenprofile zeigen, dass für zukünftige Tiefbohrungen die am leichtesten interpretierbaren klimatischen Tatsachen in den kontinentaleren Gebieten zu finden sind, - an der Ostküste und auf dem Plateau im Süden der Region. Der Grad der Kontinentalität bestimmter Stellen spiegelt sich in der Amplitude der Jahreswelle im oberen Teil des Isotopenverhältnisprofils ebenso wider wie in der Akkumulationsrate.

\section{INTRODUCTION}

The Glaciology of the Antarctic Peninsula (GAP) project has a prime objective to establish a record of climatic change in the area over the last 500 to 1000 years (Swithinbank, 1974). The Antarctic Peninsula is the only land mass that cuts across the sub-Antarctic zone which couples the circulation of lower latitudes with the polar heat sink. It separates the maritime climate of the Bellingshausen Sea from the modified continental climate to the east (Schwerdtfeger, 1970, p. 320-22, 1975; Martin and Peel, 1978). Variations with time in the balance between maritime and continental climate at sites on the Antarctic Peninsula should reflect changes in one of the 
major driving forces of climate. The ultimate objective is to establish a chain of ice-coring sites that will connect the climatic record deduced from the deep core at Byrd Station (Johnsen and others, 1972) with the record from other continents. The analysis of these data might help to resolve the ambiguity between elevation change and climate change which complicates the interpretation of records from such single-core studies.

The concentration of $\mathrm{H}_{2}{ }^{18} \mathrm{O}$ in a natural water sample may be expressed as a relative difference $\left(\delta^{18} \mathrm{O}\right)$ with respect to Standard Mean Ocean Water (SMOW). A broad understanding of the main features of the relationship between $\delta^{18} \mathrm{O}$ and air temperature at high latitudes has been achieved using the assumption that condensation processes which take place during the cooling of a moist air mass proceed under Rayleigh conditions, where condensation occurs at equilibrium and the condensate is removed from the system immediately after formation. At any stage of the condensation process the ratio $\alpha$ of the isotopic composition of the condensate to that of the vapour is almost constant (slightly temperature dependent) and is approximately equal to the ratio of the vapour pressures of the two isotopes (Dansgaard, 1961, 1964).

Data from higher latitudes often show simple linear correlations between mean annual surface temperature and mean annual $\delta$ values in the snow-fall. Under conditions where precipitation falls as snow, there is negligible alteration of the isotopic composition of falling precipitation by isotopic fractionation arising from re-evaporation or by exchange with the vapour, and the simple model may approximate to real conditions (Aldaz and Deutsch, 1967). In polar regions precipitation is also formed at lower altitudes so that the surface temperature often closely approximates to the condensation temperature used in the simple model. Data compiled by Dansgaard and others (1973) from Antarctica fall about two distinct linear regressions corresponding to East and West Antarctic sampling stations. Above $-20^{\circ} \mathrm{C}$ in East Antarctica there appears to be no significant variation of $\delta$ with temperature; the West Antarctic data do not extend to this temperature range. Lorius and Merlivat (1977) determined a detailed $\delta$ and surface-temperature profile along an $850 \mathrm{~km}$ axis in East Antarctica. A good linear relationship was observed, although the gradient differs by $25 \%$ from the previous East Antarctic plot. Above $-20^{\circ} \mathrm{C}$ (below $1000 \mathrm{~m}$ altitude) the value was similarly virtually invariant with increasing temperature.

Because there are apparently large systematic differences in fractionation behaviour between different regions in Antarctica it is vital that the fractionation mechanism in recent snows should be investigated in any area where deeper drilling is planned. This is particularly important in a topographically complicated area like the Antarctic Peninsula where mean annual temperatures lie within a range where the $\delta$ values have been reported to be temperature-insensitive in other parts of Antarctica. In addition we might not expect to see a close relationship between $\delta$ values and temperature near great surface slopes because in any one precipitation event the snow falling both on highland areas and intermediate low-lying areas is likely to have originated at a similar point in the condensation column (Ambach and others, 1968).

As a first objective we have therefore collected as many hand-drilled $10 \mathrm{~m}$ cores as possible from a wide range of environments. Analysis of the isotopic composition of these samples should identify any systematic relation between $\delta$ and surface temperature, and should also aid the selection of sites for deeper drilling.

\section{SAMPle COllection}

During the period 1974 to $1976,10 \mathrm{~m}$ cores were collected at 25 locations (Fig. 1). The network was designed to characterize climatic variations both along the spine of the mountain chain and across the region from west to east. Other stations were selected to represent both the western maritime climate and the east-coast modified-continental climate. Additional samples were taken from representative snow-dome sites which will be preferred for deeper drilling studies (Swithinbank, 1974) because it is unlikely that at these locations the ice has moved 


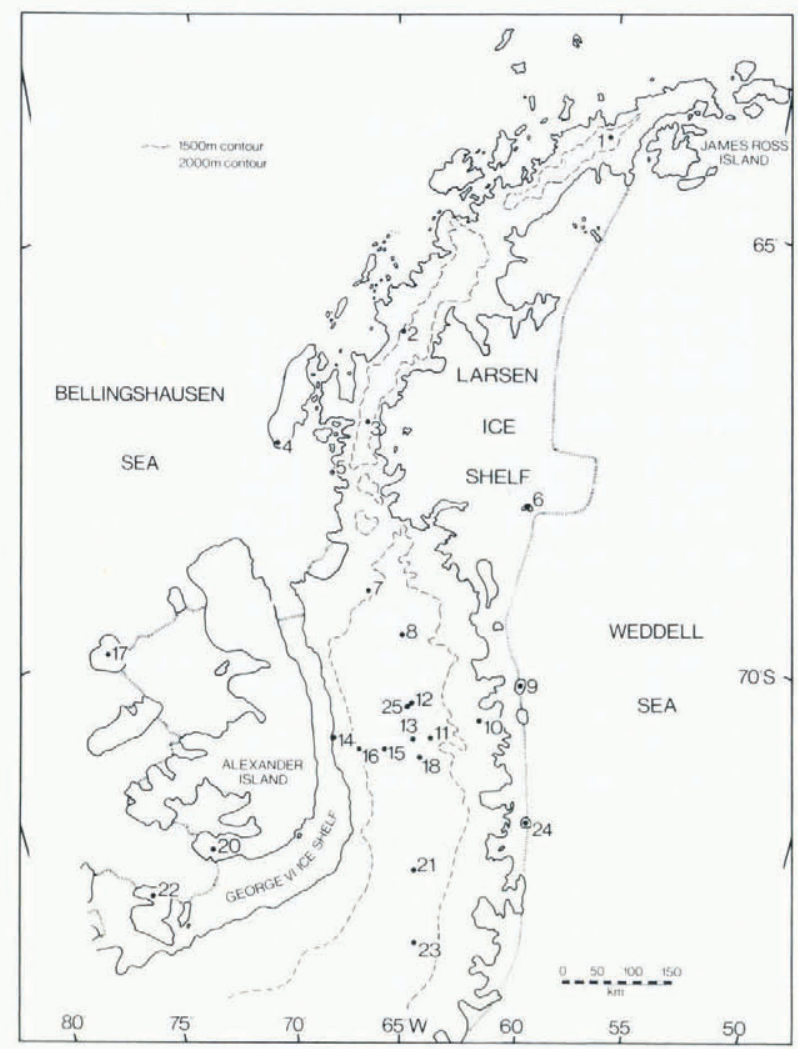

Fig. 1. Distribution of sample sites.

significantly since it was deposited. $10 \mathrm{~m}$ temperatures, which were routinely recorded at each site, have been correlated with altitude and latitude (Martin and Peel, 1978). Samples were collected routinely at a frequency of twenty per estimated annual accumulation layer through the upper two metres of accumulation, thereafter samples were cut in equal lengths to ensure at least ten samples per annual layer in a continuous profile along the core. In addition a continuous sequence of samples from each bore hole was returned for analysis of total $\beta$ activity. Samples were melted in the field, bottled in polythene vials, and returned to the Geophysical Isotope Laboratory, University of Copenhagen for analysis. Whenever possible samples were kept frozen.

\section{Mean $\delta^{18} \mathrm{O}$ versus $10 \mathrm{~m}$ temperature}

Table I collates the sample-site latitudes, longitudes, $10 \mathrm{~m}$ temperatures, altitudes, annual accumulation (ice equivalent), and weighted mean oxygen-isotope ratios. The annual accumulation has been derived using datable horizons in the observed $\beta$-activity profiles, supplemented by an interpretation of annual cycles in the oxygen-isotope ratio. The mean oxygen isotope ratio is plotted as a function of the $10 \mathrm{~m}$ temperature in Figure 2; for comparison mean lines are plotted through data reported by Dansgaard and others (1973) for East Antarctic stations and by Lorius and Merlivat (1977) for another part of East Antarctica. In addition a mean line is plotted through data collected at Amundsen-Scott South Pole station (Aldaz and Deutsch, 1967) for individual snowfall samples. In this case and for a similar line 
TABLE I. MEAN STABLE-ISOTOPE RATIOS AND 10 m TEMPERATURES FOR THE SAMPLING NETWORK

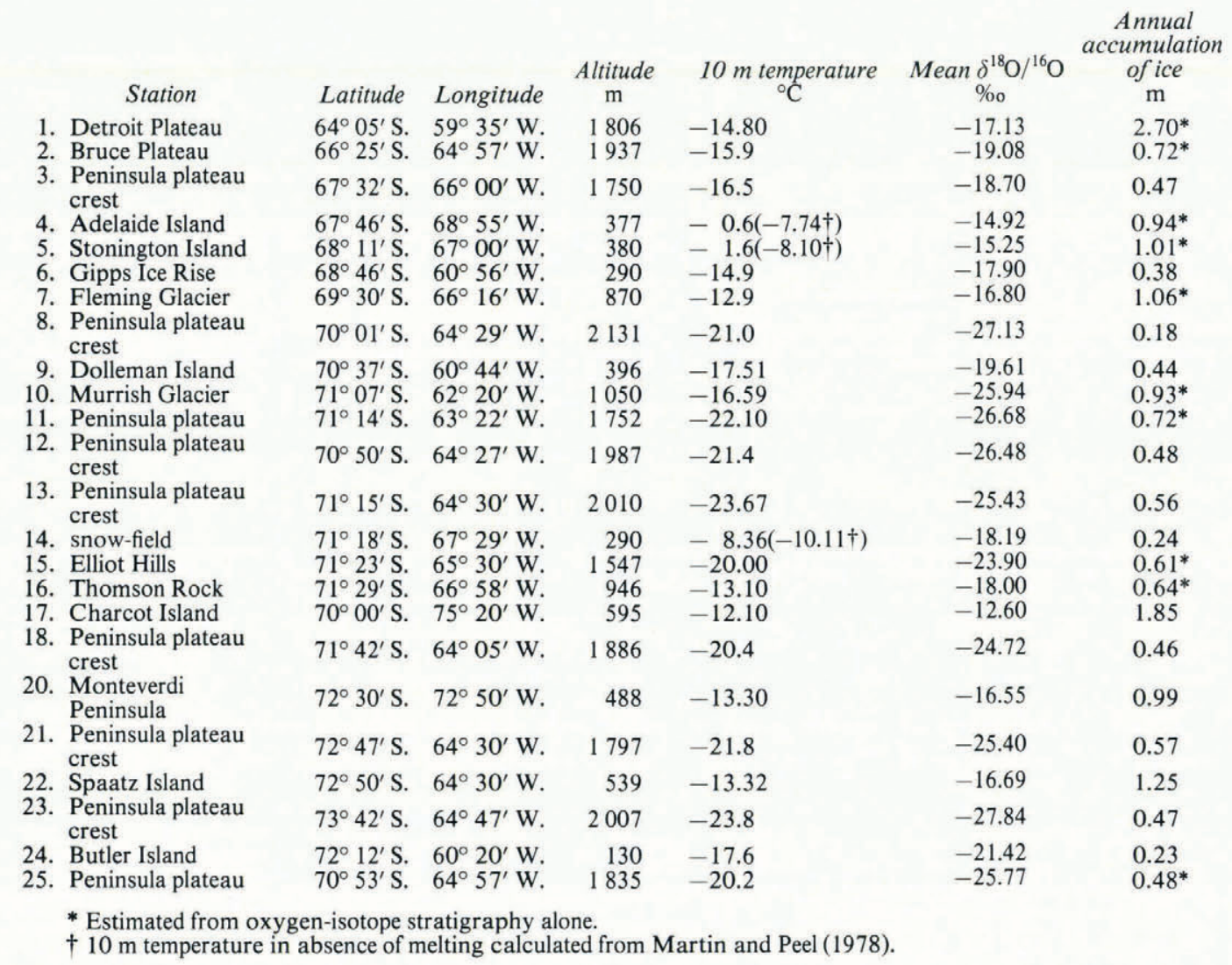

plotted for samples from Roi Baudouin Base (lat. $70^{\circ} 26^{\prime}$ S., long. $24^{\circ} 17^{\prime}$ E.), a coastal East Antarctic station (Picciotto and others, 1960), the temperature is that of the estimated condensation level. Additional points for the Antarctic Peninsula and neighbouring regions were obtained by taking a weighted mean of $\delta$ values of monthly snow-sample collections (International Atomic Energy Agency, 1973, 1975) at Argentine Islands in 1968, 1969, 1970, and 1971 and Halley Bay (lat. $75^{\circ} 31^{\prime}$ S., long. $26^{\circ} 37^{\prime}$ W.) in 1969, 1970, and 1971.

The year-to-year variation in mean annual temperature in the Antarctic Peninsula typically averages $1.2 \mathrm{deg}$ with a standard deviation about the mean of $1.6 \mathrm{deg}$ during the period 1948 to 1972 (personal communication from D. W. S. Limbert). In view of this large swing in mean annual temperature and because the mean $\delta$ value represents a variable average of from 3 to 20 years of accumulation whereas the $10 \mathrm{~m}$ temperature is sensitive to year-by-year changes, the trend of the $\delta$ curve appears smooth. That the data (Fig. 2c) of Picciotto and others (1960) agree closely with the Antarctic Peninsula values may be partially coincidental, but it does suggest that, to a first approximation, the mean annual surface temperature may be considered equal to the condensation temperature in this area, the averaging effect of many snow-falls tending to cancel short-term deviations. Data for continental East Antarctic stations, plotted against surface temperature, are seen to deviate from the Peninsula curve, the deviation tending to increase with decreasing temperature. This may reflect the increasing prevalence of stable inversions on the continental ice sheet, a condition that most commonly occurs during the winter. Under inversion conditions the condensation temperature will be consistently higher than 


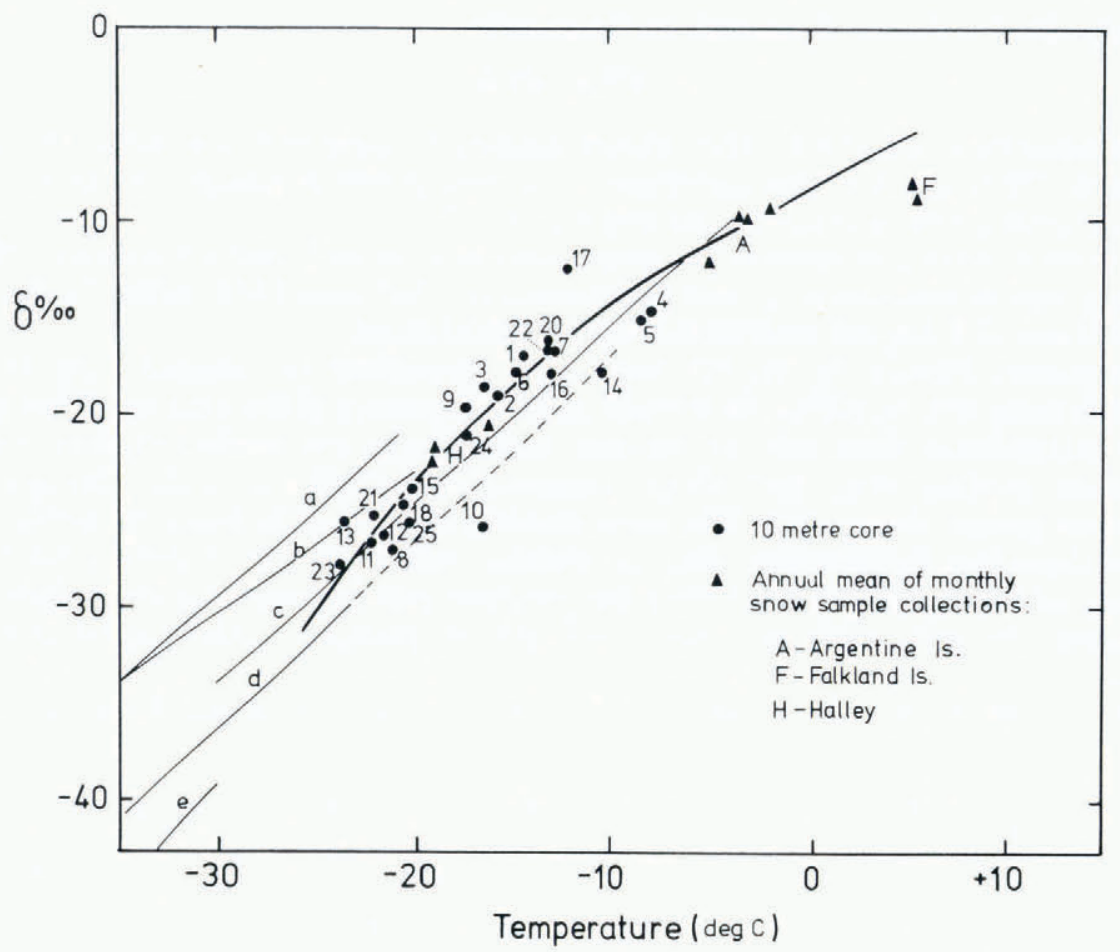

Fig. 2. Mean stable-isotope ratios ( $\delta$ values) plotted against mean annual air temperature ( 10 m temperature or mean annual daily temperatures) for the Antarctic Peninsula network in comparison with data reported for other regions of Antarctica. a: East Antarctica (Dansgaard and others, 1973); b: East Antarctica (Lorius and Merlivat, 1977); c: Roi Boudouin base (Picciotto and others, 1960); d: West Antarctica (Dansgaard and others, 1973); e: Amundsen-Scott Station (Aldaz and Deutsch, 1967).

the surface temperature. This is supported by the fact that data for Amundsen-Scott station (Fig. 2e), using estimated condensation temperatures, fit more closely to the trend observed for the Antarctic Peninsula and West Antarctica (Fig. 2d) than to the East Antarctic data (Fig. 2a, b) which refer to surface temperatures.

The form of the Antarctic Peninsula curve may be compared with that predicted by a simple model of the isotopic fractionation of water that was developed by Dansgaard $(1961,1964)$. Condensation of the vapour at high latitudes is considered to occur under Rayleigh conditions. If vapour initially saturated at temperature $t_{0}$ is brought to a lower temperature $t$, in incremental steps of $\Delta t$, then the relative deviation $\delta$ in parts per thousand (\%o) of the ${ }^{18} \mathrm{O}$ content of the condensate compared with that of the water initially in equilibrium with the vapour is given by:

$$
\delta_{t}=\left[\frac{\alpha_{t}}{\alpha_{t+\Delta t}} F_{\mathrm{v}}^{\left(\alpha_{\mathrm{m}}-1\right)}\left(1+\delta_{t+\Delta t}\right)-1\right] \times 1000
$$

where $\alpha_{t}$ is the fractionation factor at temperature $t, \alpha_{\mathrm{m}}$ the fractionation factor at $(t+\Delta t / 2)$ and $F_{\mathrm{v}}$ is the remaining fraction of the vapour phase at $t$ compared with that at $t+\Delta t$. Since data for $\mathrm{H}_{2}{ }^{18} \mathrm{O}$ fractionation factors below $0^{\circ} \mathrm{C}$ were lacking, calculations were initially made for HDO fractionation using corresponding factors which were determined to $-20^{\circ} \mathrm{C}$ over water and to $-40^{\circ} \mathrm{C}$ over ice by Merlivat and Nieff (1967). The equivalent $\delta^{18} \mathrm{O}$ values for the condensate 
were finally calculated using the empirical relationship:

$$
\delta^{18} \mathrm{O}=\delta \mathrm{D} / 8
$$

first determined by Craig (1961). This relation appears to apply widely in natural precipitation (Dansgaard, 1964) and has been confirmed at several points in Antarctica (see for example Epstein and others, 1965 and Lorius and Merlivat, 1977).

Values for $F_{\mathrm{v}}$ were calculated as the mixing ratio at pressure $p_{t}$ and temperature $t$ divided by the mixing ratio at pressure $p_{t-\Delta t}$ and temperature $(t-\Delta t)$ (List, 1949, tables 73 and 74). An incremental step of 1 deg was used throughout the calculations.

Fractionation factors for $\mathrm{H}_{2}{ }^{18} \mathrm{O}$ have been determined by Majoube (1971) for the temperature range $0^{\circ} \mathrm{C}$ to $100^{\circ} \mathrm{C}$. As a check on the consistency of the data and of our approach we have extrapolated these data to sub-zero temperatures and applied them to one of the condensation profiles (Fig. 3 $\mathrm{a}^{\prime}$ ) where condensation occurs as water throughout. For temperatures greater than $-20^{\circ} \mathrm{C}$ this curve deviates less than $2 \%$ from the profile obtained using the deuterium fractionation data of Merlivat and Nieff. For internal consistency the remaining profiles have been derived using the deuterium fractionation data which relate to direct measurements on both water and ice at sub-zero temperatures under similar experimental conditions.

In the simple model, air is assumed to equilibrate with Standard Mean Ocean Water

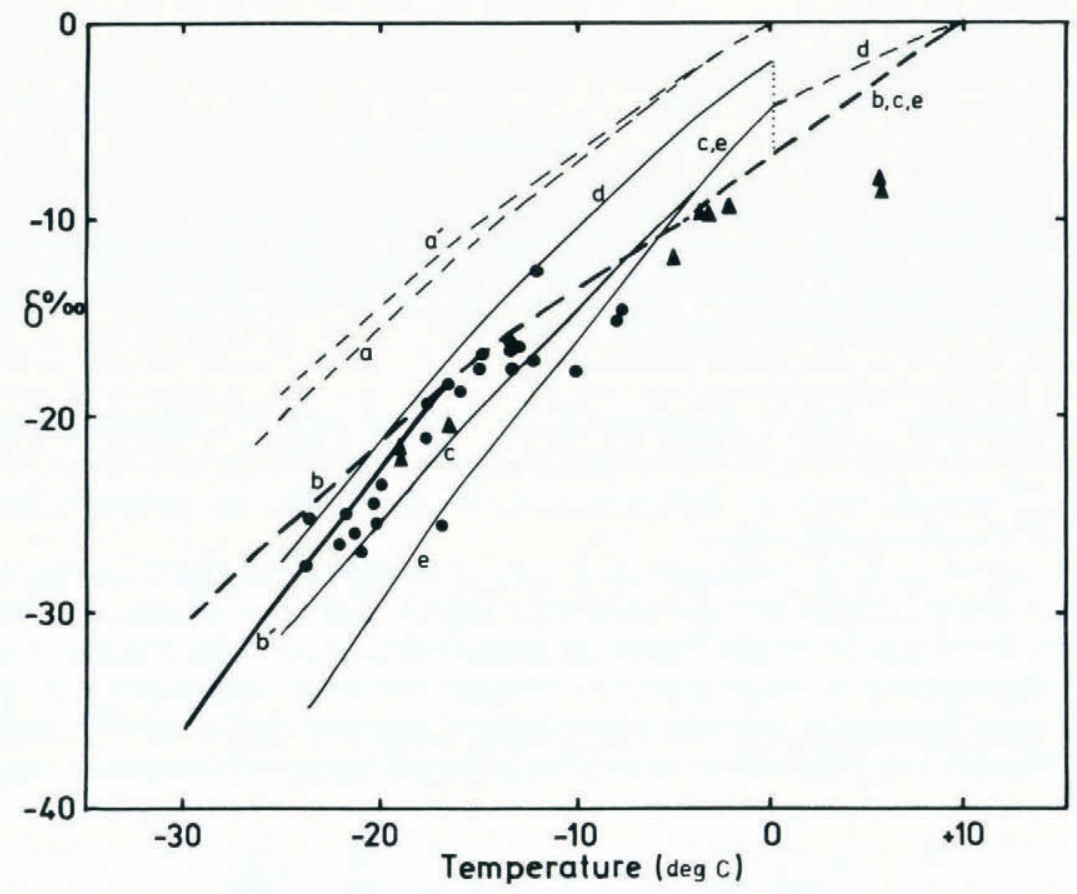

Fig. 3. Comparison of Antarctic Peninsula network data (from Fig. 2) with the results obtained from simple models of the isotope fractionation mechanism. a: $t_{0}=0^{\circ} \mathrm{C} ; p_{0}=1000$ mbar. Air mass cooled isobarically to $-4^{\circ} \mathrm{C}$, thereafter adiabatically. Condensation as water throughout. $a^{\prime}:$ As $3 a$ using fractionation factors from Majoube (1971). b: $t_{0}=10^{\circ} \mathrm{C} ; p_{0}=1000 \mathrm{mbar}$. Air mass cooled isobarically to $-4^{\circ} \mathrm{C}$, thereafter adiabatically. Condensation as water throughout. $b^{\prime}: A s$ with condensation as ice below $-18^{\circ} \mathrm{C}$. $c: t_{0}=10^{\circ} \mathrm{C}$; $p_{0}=1000$ mbar. Air mass cooled isobarically to $-4^{\circ} \mathrm{C}$, thereafter adiabatically. Condensation as ice when $t \leqslant 0^{\circ} \mathrm{C}$. d: $t_{0}=10^{\circ} \mathrm{C} ; p_{0}=1000 \mathrm{mbar}$. Air mass cooled adiabatically throughout. Condensation as ice when $t \leqslant 0^{\circ} \mathrm{C}$. e: $t_{0}=10^{\circ} \mathrm{C} ; p_{0}=1000 \mathrm{mbar}$. Air mass cooled isobarically throughout. Condensation as ice when $t \leqslant 0^{\circ} \mathrm{C}$. 
(SMOW) at temperature $t_{0}$ and 1000 mbar or, more realistically, the initial mixing ratio is equal to the saturation mixing ratio at $t_{0}$. It can be cooled to the final temperature $t$ by two extreme mechanisms or by a combination of them: isobaric cooling and adiabatic cooling. The former may be considered to be more dominant during the movement of air masses to higher latitudes across the oceans and over pack ice, the latter almost certainly regulates the temperature of an air mass once it has reached the coast of the Antarctic Peninsula (Martin and Peel, 1978). In calculating the fractionation behaviour for adiabatic cooling, the pressure $p$ at a given temperature $t$ was determined from tables of $p$ versus $t$ along saturation pseudoadiabats (Letestu, 1966, table 4.15.1).

In Figure 3 the Antarctic Peninsula data are compared with the results of applying Equation (1) to simple models of air-mass temperature/pressure histories which are believed to represent the range of behaviour of air masses approaching the region. Breaks in the curves are caused by jumps in the calculated value of $\alpha$ and in the mixing ratio during the phase change from water to ice. A comparison of curves $3 a$ and $3 b$ shows that varying the effective source temperature has little influence on the shape of the fractionation curve. Curves $3 \mathrm{~d}$ and $3 \mathrm{e}$ represent respectively the extremes of total adiabatic cooling and total isobaric cooling. Curve $3 \mathrm{c}$ represents more realistic intermediate behaviour in which an air mass is cooled isobarically to $-4^{\circ} \mathrm{C}$, thereafter adiabatically.

The profiles are sensitive to the temperatures selected for the point at which condensation is in the form of ice because the mixing ratios and the fractionation factors are a function of the state of the water-compare curve $3 \mathrm{~b}$ in which condensation is considered to occur over water throughout, with curve $3 \mathrm{c}$ in which condensation occurs as ice below $0^{\circ} \mathrm{C}$. For condensation processes inside a cloud the transition temperature is likely to be lower than $-15^{\circ} \mathrm{C}$ owing to the rarity of efficient ice-forming nuclei (Mason, 1971, p. 155) particularly in a marine environment. If precipitation from predominantly water droplet clouds is then considered to develop according to the Bergeron-Findeison theory (Mason, 1971, p. 284) a few droplets will be induced to freeze by ice nuclei and will grow rapidly by sublimation from the liquid phase onto the ice surfaces. Once they have achieved a fall velocity, the ice crystals will collide with and collect supercooled cloud droplets which will freeze on impact. Thus the isotopic composition of snow falling to the ground will be more or less biased towards a liquid/vapour condensation equilibrium composition. Furthermore snow-surface riming from supercooled fogs occurs frequently in the region and may be a significant contributor to the annual accumulation. These ice deposits will have an isotopic composition similar to that which would have been obtained had precipitation of water droplets occurred. Ice crystals generally predominate in clouds where temperatures are below about $-20^{\circ} \mathrm{C}$ (Mason, 1971, p. 289). Further cooling of the cloud will result in direct condensation as ice onto the ice crystals. Curve $3 b^{\prime}$ assumes that condensation occurs as ice below $-18^{\circ} \mathrm{C}$. The gradient of this curve is more comparable with that of the Antarctic Peninsula data than is the gradient of curve $3 \mathrm{c}$, where no allowance for supercooling has been made.

The relationship between $\delta$ and temperature for the Antarctic Peninsula appears to be satisfactorily described by a simple model where, on average, an air mass in equilibrium with SMOW at $+10^{\circ} \mathrm{C}$ (or more realistically with a mixing ratio of $7.8 \mathrm{~g}$ of water per $\mathrm{kg}$ of air) cools largely isobarically as it moves polewards across the southern ocean until it reaches the coast of the Antarctic Peninsula where the mean annual temperature is typically $-4^{\circ} \mathrm{C}$. Further cooling is accompanied by adiabatic uplift of the air mass as it moves into the mountains. Evidence for precipitation occurring as a result of adiabatic uplift was obtained by collecting two series of samples of freshly fallen snow along one axis of an ice dome (Monteverdi Peninsula). The event 1 series (Fig. 4) represents the oxygen-isotope data for samples from an $0.5 \mathrm{~cm}$ rime layer which had formed immediately prior to the collection. The event 2 series represents the collection of snow that had fallen under very light wind conditions $\left(<1 \mathrm{~m} \mathrm{~s}^{-1}\right)$ from a stratus cloud base between the surface and $300 \mathrm{~m}$. The gradients of these curves are $-0.7 \% / 100 \mathrm{~m}$ and 


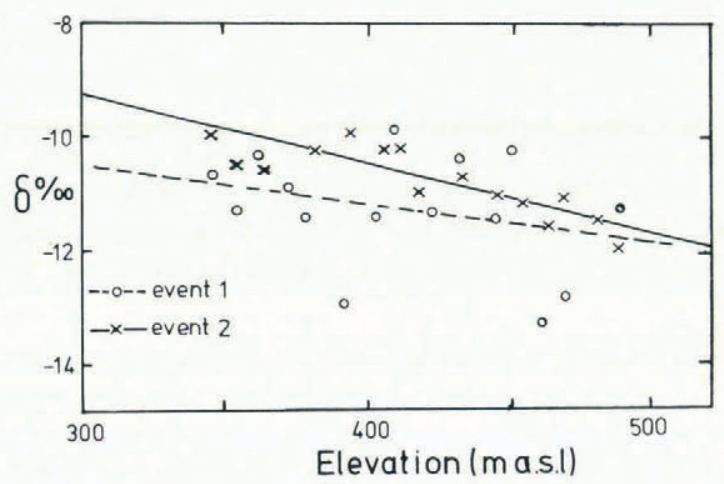

Fig. 4. Dependence of stable-isotope ratio on altitude for samples collected during two precipitation events, Monteverdi Peninsula, January 1977.

$-1.1 \%$ o/ $100 \mathrm{~m}$ respectively. Converting these to equivalent temperature gradients using Figure 2 , the corresponding temperature lapse-rates are $-0.77 \mathrm{deg} / 100 \mathrm{~m}$ and $-1.2 \mathrm{deg} / 100 \mathrm{~m}$ which may be compared with the annual mean temperature lapse-rate with altitude for the Peninsula of $-0.68 \mathrm{deg} / 100 \mathrm{~m}$ (Martin and Peel, 1978).

The smooth trend of the mean curves of $\delta$ versus temperature does suggest that on the average, precipitating air masses throughout the region have a similar origin. This is physically reasonable because the Peninsula lies across the tracks of depressions moving in from the wellmixed westerly depression belt. The mixing ratio of the mean parent air mass is typical of maritime sub-tropical air masses (Barry and Chorley, 1971, p. 164) which are expected to be the principal source of moist air masses moving towards the Peninsula.

In the real situation the problem is much more complicated because air masses may become modified by mixing with other air masses of different isotopic composition (i.e. not lying on the same $\delta / t$ curve). Also re-evaporation and isotopic exchange effects may be important during the early stages of the condensation process where precipitation falls as rain. As these effects are likely to occur randomly, and largely before the air mass has reached the Antarctic Peninsula, their influence over long periods should merely affect the apparent origin of the $\delta / t$ curve, whose shape would remain generally unchanged. In travelling across the Southern Oceans en route to the Peninsula an air mass is likely to take up newly evaporated ocean water vapour stabilizing the $\delta$ value of the precipitation in coastal locations. This may explain the similarity between the $\delta$ values of precipitation at Argentine Islands and at the Falkland Islands which lie outside the Antarctic Convergence in the same longitudinal sector as the Peninsula (International Atomic Energy Agency, 1970).

Three Antarctic Peninsula stations (10, 14, and 17) deviate significantly from the smooth trend of the other stations. Station 14, on an incline, suffers extensive melt during the summer. Run-off derived from summer snow and rainwater of higher $\delta$ value evidently biases these data towards more negative values. This contrasts with behaviour in regions where there is a small difference between the isotopic content of winter and summer precipitation and isotopic exchange effects between water and ice tend to raise the $\delta$ value of the firn where percolation occurs (Árnason, 1976). Stations 4 and 5 are similarly affected albeit to a lesser extent. Katabatic winds, which tend to redeposit snow that originally fell at a higher altitude and hence a lower temperature, are probably responsible for depressing the $\delta$ value at Murrish Glacier (10). The detailed profile at Charcot Island (17) shows that the accumulation rate is approximately three metres per annum, so that a ten-metre core samples only three years' accumulation. The profile appears to incorporate one more summer than the number of winters. Taken together 
with the fact that the other isotope profiles show that the period was isotopically abnormally warm, this may account for the approximately $+3 \%$ o deviation of Charcot Island's $\delta$ value.

\section{ANALYSIS OF OXYGEN-ISOTOPE RATIO PROFILES}

$\delta$-value depth profiles that represent the range observed in the Antarctic Peninsula are presented in Figure 5. These have been correlated with the corresponding specific total $\beta$-activity profiles in an attempt to identify annual layers. Radioactive fall-out from a series of Soviet nuclear weapon tests in the northern hemisphere during 1961-62 reached a broad maximum in Antarctica about two years later due to the relatively slow inter-hemispherical exchange of stratospheric air (Clausen and Dansgaard, 1977). Whereas the resulting typical peak activity of Greenland snow was 2300 disintegrations per hour per kilogramme of firn, the corresponding activity in the Antarctic Peninsula is only approximately $400 \mathrm{dph} / \mathrm{kg}$ against a background of $200 \mathrm{dph} / \mathrm{kg}$ firn. This horizon (summer 1964/65) may be identified in all the Peninsula stations where the $10 \mathrm{~m}$ record is sufficiently long. Elevated specific $\beta$ activities occur during the period 1970-73. These are thought to have arisen largely from the French weapons tests which were carried out in low southern latitudes during 1968 and 1970 (Clausen and Dansgaard, 1977).

At station 14 where the accumulation rate is particularly small, the record extends beyond the summer of 1954-55, where the activity arising from the "Castle" series of weapons tests may be observed as a shift in activity from a background level of $50-100 \mathrm{dph} / \mathrm{kg}$ to approximately $300 \mathrm{dph} / \mathrm{kg}$. The activity of the $1964-65$ peak is $1100 \mathrm{dph} / \mathrm{kg}$ compared with the range $380-600 \mathrm{dph} / \mathrm{kg}$ observed elsewhere in the region. Station 14 , which lies within $1 \mathrm{~km}$ of exposed rock, suffers from extensive percolation of summer melt water and it is likely that the activity has been concentrated by adsorption of radionucleides onto thin dust layers. The shift in activity for $1954 / 55$ (to $250 \mathrm{dph} / \mathrm{kg}$ ) was also observed at $6 \mathrm{~m}$ depth at station 8 and at $10 \mathrm{~m}$ depth at Butler Island (station 24).

A prime requirement at future deeper drilling sites is that for convenience of dating there should be simple annual cycles in the $\delta$-value profile, of sufficient amplitude to ensure that they are preserved through the firnification process. The amplitude of the annual temperature cycle, which determines the degree of continentality, may be related to the amplitude of the $\delta$-value cycle in the same manner as the annual means are related. Thus a detailed examination of the amplitude of individual isotope profiles should also provide additional evidence for the degree of continentality of particular sites. However, any systematic imbalance in the distribution of accumulation throughout the year will have a distorting effect on the profile. Moreover, $\delta$ profiles will be more or less smoothed by diffusion during firnification and in order to re-establish the initial shape of the seasonal $\delta$ cycles they require correction (Johnsen, 1977; Hammer and others, 1978).

Figure 5a and b shows complex isotope profiles typical of west-coast sites affected by percolation of summer melt water (particularly at station 7 on Fleming Glacier), by a large and complex annual accumulation (particularly at station 17 on Charcot Island), and by the proximity of a sea-ice cover that forms, breaks up, and reforms irregularly during a large proportion of the year. The maritime nature of the climate on the western side of the Peninsula results in a small-amplitude annual temperature cycle of about $5.5 \mathrm{deg}$ (Limbert and Loan, 1976; Schwerdtfeger, 1974). The corresponding $\delta$ cycle is then of the same order of magnitude as the random fluctuations that are superimposed on it, so that the resulting profiles cannot be interpreted objectively.

The features of the Peninsula plateau sites from lat. $70^{\circ} \mathrm{S}$. northwards, typified by Figure $5 \mathrm{c}$, are similar to those for the west-coast sites but lack short-term jumps probably due to a lower accumulation rate, greater remoteness from marine influences, and almost complete lack of summer melt layers. The dates assigned to winter layers in Figure $5 \mathrm{c}$ are placed primarily with regard to features in the $\beta$ profile and illustrate the difficulty in interpreting annual layers from 


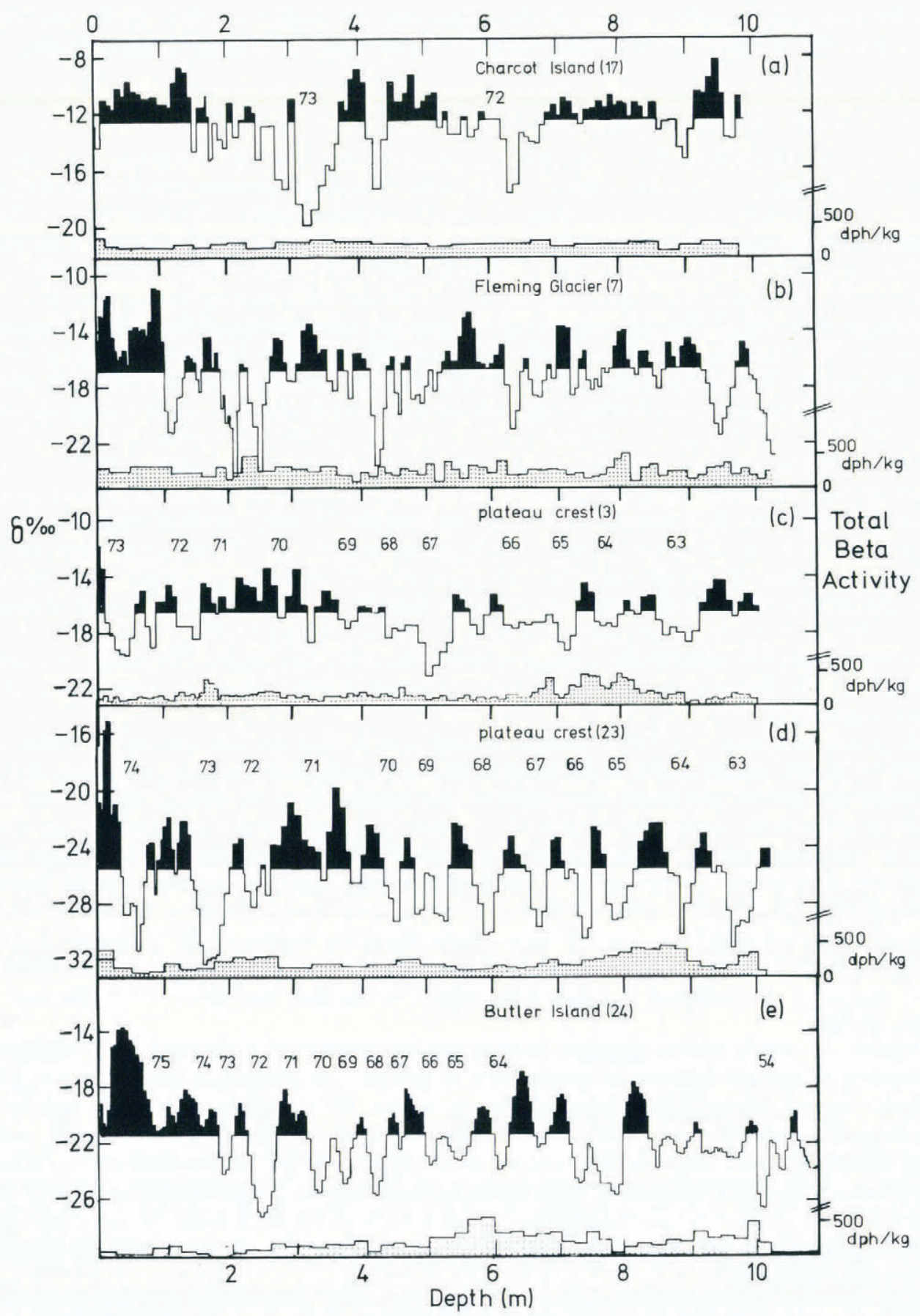

Fig. 5. Typical $\delta$-value and $\beta$-activity profiles obtained along $10 \mathrm{~m}$ cores. a: Charcot Island (17) (lat. $69^{\circ} 47^{\prime} S$., long. $75^{\circ} 13^{\prime}$ W.). b: Fleming Glacier (7) (lat. $69^{\circ} 30^{\prime}$ S., long. $66^{\circ} 16^{\prime}$ W.). c: February dome (3) (lat. $67^{\circ} 32^{\prime}$ S., long. $66^{\circ} 00^{\prime} \mathrm{W}$.). d: Station 23 (lat. $73^{\circ} 42^{\prime} \mathrm{S}$., long. $64^{\circ} 47^{\prime} \mathrm{W}$.). e: Butler Island (9) (lat. $72^{\circ} 12^{\prime} \mathrm{S}$., long. $60^{\circ} 20^{\prime} \mathrm{W}$.). 
oxygen-isotope stratigraphy. Profiles drawn for plateau sites progressively farther south along the spine of the peninsula show a steadily increasing annual amplitude in the $\delta$ value that masks the random fluctuations which complicate profiles from more northerly stations. By lat. $73^{\circ} \mathrm{S}$. (station 21) the annual cycle of the profile has become almost unequivocal and its peak-to-peak amplitude of the cycle at $10 \mathrm{~m}$ depth $(7 \%$ ) combined with a $50 \mathrm{~cm}$ annual accumulation of ice, indicates that the profile will not be destroyed by diffusion in a deeper core from this site (Dansgaard and others, 1973; Johnsen, 1977). At station 23 (Fig. 5d) the degree of continentality indicated by the isotope profile amplitude is comparable with that of Halley (International Atomic Energy Agency, 1973, 1975). Nevertheless in the majority of cases some annual layers, particularly near the surface, contain double $\delta$ peaks as found also in Greenland (Hammer and others, 1978, fig. 4). Thus year by year dating using seasonal $\delta$ cycles is not straightforward and any interpretation must be tentative.

A major feature of the Antarctic Peninsula is its function as a climatic divide (Schwerdtfeger, 1970, p 320-22, 1975). Analysis of the $10 \mathrm{~m}$ temperature data (Martin and Peel, 1978) shows that the boundary between the maritime west-coast and more continental east-coast climatic regimes probably occurs close to the foot of the eastern escarpment. The oxygen-isotope profiles support this idea. A profile for Gipps Ice Rise at lat. $69^{\circ} \mathrm{S}$. on the east coast exhibits cycles with a similar amplitude to those found on the plateau at lat. $73^{\circ} \mathrm{S}$. The amplitudes of the profiles at Butler Island in lat. $72^{\circ} \mathrm{S}$., (Fig. 5e) and at Dolleman Island (lat. $70.5^{\circ} \mathrm{S}$.) are $25 \%$ greater than those from the plateau at lat. $74^{\circ} \mathrm{S}$. (station 23 ), suggesting that the east-coast climate south of lat. $70^{\circ} \mathrm{S}$. is more continental than Halley Bay.

Accumulation rates throughout the Peninsula are generally greater than the $20 \mathrm{~cm}$ ice per annum necessary to prevent the obliteration of annual cycles by diffusion during the firnification process (Johnsen, 1977). At Butler Island, where the annual accumulation is only marginally greater than $20 \mathrm{~cm}$, the $\beta$-activity horizons show that at least two annual cycles between 1954 and 1964 have been lost. In selecting deeper drilling sites the most important criterion will be that the amplitude of the annual isotope cycle should be strong compared with random fluctuations. Our results suggest that the most suitable areas are on the east coast south of lat. $68^{\circ} \mathrm{S}$. (provided that the annual accumulation is sufficiently large) and on the plateau south of $73^{\circ} \mathrm{S}$. where the profiles improve dramatically with higher latitudes.

In qualitatively comparing the degree of continentality at different locations the effect of smoothing has been neglected. Johnsen (1977) has shown that the mean-square displacement of a water molecule by the end of the firnification process (essentially when a critical density of $0.55 \mathrm{Mg} \mathrm{m}^{-3}$ has been surpassed) is independent of the accumulation rate and only slightly dependent on the temperature. A diffusion length of $7-8 \mathrm{~cm}$ of ice equivalent was demonstrated in widely different glaciological regimes. The degree of smoothing during firnification is then predominantly a function of the depth wavelength of the $\delta$ cycle (accumulation rate). As accumulation tends to decrease with increasing continentality in the Peninsula the effect will be an increasing underestimate of the degree of continentality as deduced from the amplitude of the stable-isotope ratio.

\section{Conclusions}

1. There is a systematic relationship between mean oxygen-isotope ratio and $10 \mathrm{~m}$ temperature throughout the Antarctic Peninsula. The data are consistent with those obtained in other parts of the continent that have a simpler topography. The relationship with temperature is similar to that derived from a simple model in which an air mass with maritime subtropical characteristics is cooled in part isobarically to $-4^{\circ} \mathrm{C}$ and subsequently adiabatically as it travels towards the peninsula. A comparison with data obtained in other parts of Antarctica for which direct estimates of the true condensation temperature can be made suggests that, on average, surface temperatures in the Antarctic Peninsula lie close to the condensation temperature. 
2. The main criteria for selecting a deep-drilling site are that the climatic record from an ice core should be interpretable and that climatic events can be dated by stratigraphic and flowmodelling methods. The record should be as long as possible. On the basis of our oxygen-isotope data it appears that the best sites will be on ice rises on the east coast or on the spine of the Peninsula plateau south of lat. $73^{\circ} \mathrm{S}$. Sites on the west coast and on the plateau northward of lat. $70^{\circ} \mathrm{S}$. cannot be dated by counting stable isotope cycles.

3. The amplitude of the annual isotope-ratio wave may be used to assess the degree of continentality at a particular sampling site. The degree of continentality on the east side of lat. $69^{\circ} \mathrm{S}$. is comparable with that on the spine of the Antarctic Peninsula at lat. $73^{\circ} \mathrm{S}$. At the same time it is intermediate between that of the west coast and that of a coastal station such as Halley at the edge of the main ice sheet. The degree of continentality increases with increasing latitude and at lat. $73^{\circ} \mathrm{S}$. on the spine of the peninsula it is similar to that of Halley.

\section{MS. received 1 September 1978 and in revised form 3 December 1980}

\section{REFERENCES}

Aldaz, L., and Deutsch, S. 1967. On a relationship between air temperature and oxygen isotope ratio of snow and firn in the South Pole region. Earth and Planetary Science Letters, Vol. 3, No. 3, p. 267-73.

Ambach, W., and others. 1968. The altitude effect on the isotopic composition of precipitation and glacier ice in the Alps, by W. Ambach, W. Dansgaard, H. Eisner, and J. Møller. Tellus, Vol. 20, No. 4, p. 595-600.

Arnason, B. 1976. Groundwater systems in Iceland traced by deuterium. Visindafélag Íslendinga, 42.

Barry, R. G., and Chorley, R. J. 1971 Atmosphere, weather, and climate. London, Methuen and Co. Ltd.

Clausen, H. B., and Dansgaard, W. 1977. Less surface accumulation on the Ross Ice Shelf than hitherto assumed. [Union Géodésique et Géophysique Internationale. Association Internationale des Sciences Hydrologiques. Commission des Neiges et Glaces.] Symposium. Isotopes et impuretés dans les neiges et glaces. Actes du colloque de Grenoble, août/septembre 1975, p. 172-76. (IAHS-AISH Publication No. 118.)

Craig, H. 1961. Isotopic variations in meteoric waters. Science, Vol. 133, No. 3465, p. 1702-03.

Dansgaard, W. 1961. The isotopic composition of natural waters with special reference to the Greenland ice cap. Meddelelser om Grønland, Bd. 165, Nr. 2.

Dansgaard, W. 1964. Stable isotopes in precipitation. Tellus, Vol. 16, No. 4, p. 436-68.

Dansgaard, W., and others. 1973. Stable isotope glaciology, by W. Dansgaard, S. J. Johnsen, H. B. Clausen, and N. Gundestrup. Meddelelser om Grønland, Bd. 197, Nr. 2.

Epstein, S., and others. 1965. Six-year record of oxygen and hydrogen isotope variations in South Pole firn, by S. Epstein, R. P. Sharp, and A. J. Gow. Journal of Geophysical Research, Vol. 70, No. 8, p. 1809-14.

Hammer, C. U., and others. 1978. Dating of Greenland ice cores by flow models, isotopes, volcanic debris and continental dust, by C. U. Hammer, H. B. Clausen, W. Dansgaard, N. Gundestrup, S. J. Johnsen, and N. Reeh. Journal of Glaciology, Vol. 20, No. 82, p. 3-26.

International Atomic Energy Agency. 1970. Environmental isotope data No. 2: World survey of isotope concentration in precipitation (1964-1965). Vienna, International Atomic Energy Agency. (Technical Reports Series, No. 117.)

International Atomic Energy Agency. 1973. Environmental isotope data No. 4: World survey of isotope concentration in precipitation (1968-1969). Vienna, International Atomic Energy Agency. (Technical Reports Series, No. 147.)

International Atomic Energy Agency. 1975. Environmental isotope data No. 5: World survey of isotope concentration in precipitation (1970-1971). Vienna, International Atomic Energy Agency. (Technical Reports Series, No. 165.)

Johnsen, S. J. 1977. Stable isotope homogenization of polar firn and ice. [Union Géodesique et Geophysique Internationale. Association Internationale des Sciences Hydrologiques. Commission des Neiges et Glaces. I Symposium. Isotopes et impuretes dans les neiges et glaces. Actes du colloque de Grenoble, août/septembre 1975, p. $210-19$. (IAHS-AISH Publication No. 118.)

Johnsen, S. J., and others. 1972. Oxygen isotope profiles through the Antarctic and Greenland ice sheets, |by| S. J. Johnsen, W. Dansgaard, H. B. Clausen, C. C. Langway, Jr. Nature, Vol. 235, No. 5339, p. 429-34; Vol. 236 , No. 5344 , p. 249.

Letestu, S., ed. 1966. International meteorological tables. Geneva, World Meteorological Organization. (WMO-No. 188, TP. 94.)

Limbert, D. W. S., and Loan, R. S. B. 1976. Climatological summary for 1972. British Antarctic Survey Bulletin, No. 44 , p. $39-45$.

List, R. J. 1949. Smithsonian meteorological tables. Sixth revised edition. Smithsonian Miscellaneous Collections, Vol. 114. (Publication 4014.)

Lorius, C., and Merlivat, L. 1977. Distribution of mean surface stable isotopes in East Antarctica: observed changes with depth in the coastal area. [Union Géodésique et Géophysique Internationale. Association Internationale des Sciences Hydrologiques. Commission des Neiges et Glaces.] Symposium. Isotopes et impuretés dans les neiges et glaces. Actes du colloque de Grenoble, août/septembre 1975, p. 127-37. (IAHS-AISH Publication No. 118.)

Majoube, M. 1971. Fractionnement en oxygène 18 et en deuterium entre l'eau et sa vapeur. Journal de Chimie Physique et de Physico-Chimie Biologique, Vol. 68, No. 10, p. 1423-36. 
Martin, P. J., and Peel, D. A. 1978. The spatial distribution of $10 \mathrm{~m}$ temperatures in the Antarctic Peninsula. Journal of Glaciology, Vol. 20, No. 83, p. 311-17.

Mason, B. J. 1971. The physics of clouds. Second edition. Oxford, Clarendon Press.

Merlivat, L., and Nief, G. 1967. Fractionnement isotopique lors des changements d'état solide-vapeur et liquide-vapeur de l'eau à des températures inférieures à $0^{\circ} \mathrm{C}$. Tellus, Vol. 19, No. 1, p. 122-27.

Picciotto, E. E., and others. 1960. Isotopic composition and temperature of formation of Antarctic snows, by E. [E.] Picciotto, X. de Maere [d'Aertrycke], and I. Friedman. Nature, Vol. 187, No. 4740, p. 857-59.

Schwerdtfeger, W. 1970. The climate of the Antarctic. (In Orvig, S., ed. Climates of the polar regions. Amsterdam, Elsevier. (World Survey of Climatology, Vol. 14.))

Schwerdtfeger, W. 1974. The Antarctic Peninsula and the temperature regime of the Weddell Sea. Antarctic Journal of the United States, Vol. 9, No. 5, p. 213-14.

Schwerdtfeger, W. 1975. The effect of the Antarctic Peninsula on the temperature regime of the Weddell Sea. Monthly Weather Review, Vol. 103, No. 1, p. 45-51.

Swithinbank, C. W. M., ed. 1974. An international glaciological programme for the Antarctic Peninsula: report of a meeting held in Cambridge, England, 27-30 April 1973. Polar Record, Vol. 17, No. 106, p. 86-98. 